\title{
STUDY OF THE EFFECT OF CASTOR SEEDS (RICINUS COMMUNIS LINN.) ON OVARY FUNCTIONS AND CHARACTERS OF FEMALE RABBITS
}

\author{
BUTHYNA A. ABDULLAH ${ }^{1}$, ENTEDHAR R. SARHAT ${ }^{2}$ and SIHAM A. WADI ${ }^{3}$ \\ ${ }^{1,3}$ Dept. of Pharmacology, Collage of Veterinary Medicine, University of Tikrit, Iraq \\ ${ }^{2}$ Dept of Basic Science (Biochemistry), Dentistry College, Tikrit University, Iraq
}

Received: 15 November 2016; $\quad$ Accepted: 27 December 2016

\begin{abstract}
This study was designed to investigate the effects castor seeds (Ricinus Communis) on the ovary functions and characters of female rabbits. The study conducted on 20 of adult rabbit. Animals divided into four groups, each group 5 animals. Group (I) served as control group and received distilled water only, while group (II) has been set as treated orally with castor oil ( $0.5 \mathrm{ml} \backslash \mathrm{BW}$ for 15 days), group (III) has been treated with1 ml $\backslash \mathrm{BW}$ castor oil for 15 days, and the forth group treated with $5 \mathrm{mllBW}$ twice daily. The second group showed loss of weight, diarrhea, loss stamina, dehydration, histopathologically showed destruction of all layer of ovary and present of necrosis in the cell third group showed identical clinical sign compared to the group (II) and histopathologically showed necrosis, while forth groups death after 6 day due to high doses.
\end{abstract}

Key words: Castor Seeds (Ricinus Communis Linn.), OVARY, Female Rabbits

\section{INTRODUCTION}

Castorseeds (Ricinus communis L.) is a wild shrub from the Euphorbiaceous family and has been shown to appear in many farming systems of the world. This crop grows widely and wildly from high, medium to low rainfall areas with reports indicating that arable sites under high altitude areas generally record high seed yield per tree (Charles, 2014). Castor oil, seeds, leaves and roots have numerous medicinal importance in treatment of some disease such as peritonitis, diarrhea, dysentery, lumbago, constipation, piles, paralysis, sciatica, boils, asthma, dropsy, leprosy, arthritis, amenorrhea backache, rheumatoid arthritis, ano-rectal problems, burning feet, period pain, sores, boils, rheumatic swellings, chest, back or abdomen pain, headache, broken tooth, joint pains, pelvis pain, uterine pain, dermatitis, eczema, lactation, nodules in breasts, cracked nipples and the rheumatism (Nasir, 2011).

This plant is the most poisonous in the world. Despite this, suicides involving ingestion of castor beans are unheard of in countries like India. Poisoning occurs when animals, including humans, ingest broken seeds or break the seed by chewing: intact seeds may pass through the digestive tract without releasing the toxin (Banderjee, 1999). Various medicinal plant extracts have been tested for their antifertility activity both in male and female (Farid, 2011). A number series of

Corresponding author: Dr. BUTHYNA A. ABDULLAH E-mail address: Buthinaabad67@yahoo.com

Present address: Dept. of Pharmacology, Collage of Veterinary Medicine, University of Tikrit, Iraq studies showed that the seeds has antifertility activity it helps the inhibition of maturation of the follicle in the ovary and prevents ovulation. The sex hormone being steroidal compound's (phytosterols) and the presence of steroids in methanol extract of Ricinus communis seed produces anti-fertility effects. The changes could probably be mediated via gonadal disruption in testosterone secretion (Jehan, 1973). The present study aimed to investigate the effect of Ricinus oil as antifertility in rabbits.

\section{MATERIALS AND METHODS}

This study has been achieved in the animal house of the college of veterinary medicine / Tikrit University, during January-April 2015.

The seeds of castor bean Ricinus communis were collected from the traditional medicine market, the seeds were cleaned and washed with tap water then dried in open air and kept in special container till use. The outer husk was removed manually in order to get the white pulp, the decorticated castor seeds were pressed with mechanical hydraulic press for primary castor oil take out, and the result was friable texture material, this material mixed by the blender with petroleum ether for complete defatting of castor oil, the mixture was filtered by filter paper and special cotton tissue to separate the cake from the castor oil petroleum ether mixture. The cake was dried using desiccator by utilizing $(\mathrm{NaOH})$ and the final result was dry, whitish - beige, and fine powder kept in special container containing anti-moisture sac to avoid the moisture (Al-Tahan, 1990). 
Twenty female Rabbit weighting (1-1.5) kg. age range 5 month old were used in this experiment study, they divided in to four equal groups, 5 in each groups, each group received different treatment twice daily for 15 days as follows:-

Group (I):- Served as control group and received distilled water only,

Group (II):- Treated orally with $0.5 \mathrm{ml} \backslash \mathrm{BW}$ for 15 days,

Group (III):- Treated $1 \mathrm{ml} \backslash \mathrm{BW}$ for 15 days,

Group (IV):- Treated 5ml\BW twice daily.

The animals were killed at the day after the last dose under intensive dose of chloroform. The Ovary excised and covered with physiological normal saline and cleaned from attached fat and connective tissue. Blocks of tissues were immediately fixed in $10 \%$ neutral buffered formalin, dehydrated with graded series of ethyl alcohol and embedded in paraffin.
Photomicrographs of the stained slides were taken using digital camera attached to light microscope.

\section{RESULTS}

In the present study, reduction in the body weight of the female rabbit was observed after 7 days of administration of castor oil with symptoms of diarrhea, loss of stamina, dehydration, and death all groups were noticed at higher doses groups (IV), while in group II\&III the results of our work revealed the abnormal histopathological of the ovary that treated with castor oil when compared with to the control group (1). Figure 1(A,B) shows normal ovary layer mesothelium - tunica albacana, primary follicle, mature follicles and blood vessels. Figure 2 shows completely destruction of ovary structure (primary follicle-layer- mesothelium and oocyte), graffian follicle necrosis. Figure 3 shows ending of necrosis.
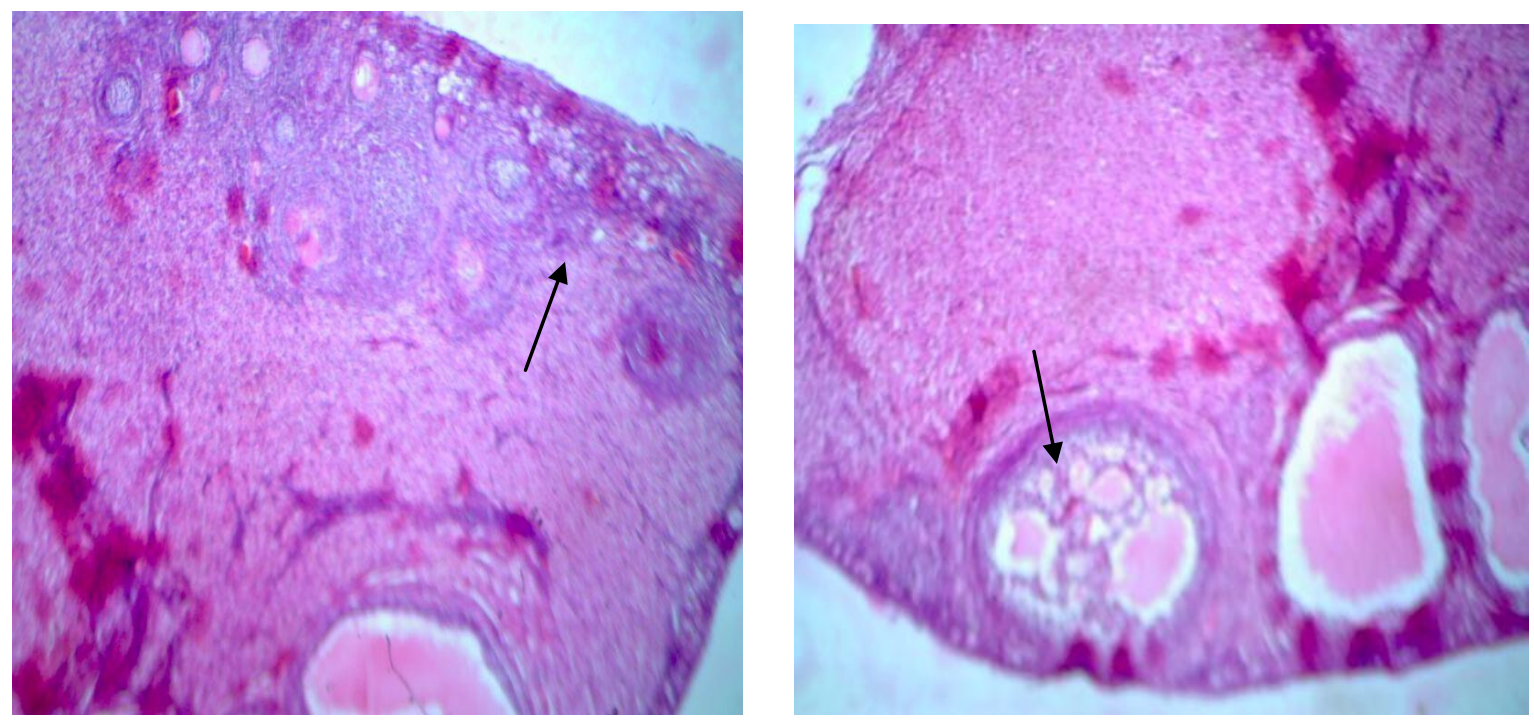

Figure (B) Figure (A)

Fig. (1- A;B):- Showed normal histological changes of rabbit ovary received distilled water (H\&EX40).

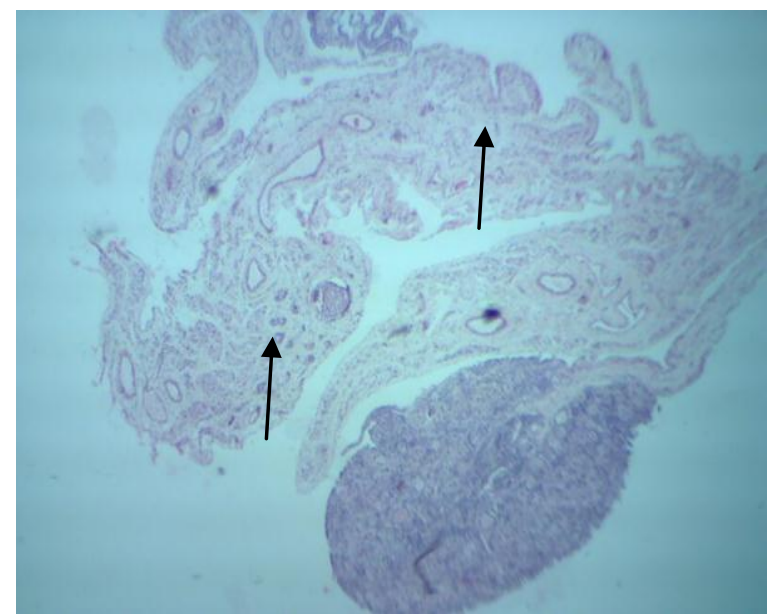

Figure (2):- Ovary female rabbit treated by $0.5 \mathrm{ml}$ of castor oil group(II) destruction of all ovary layer and present beginning of necrosis (H\&EX10)

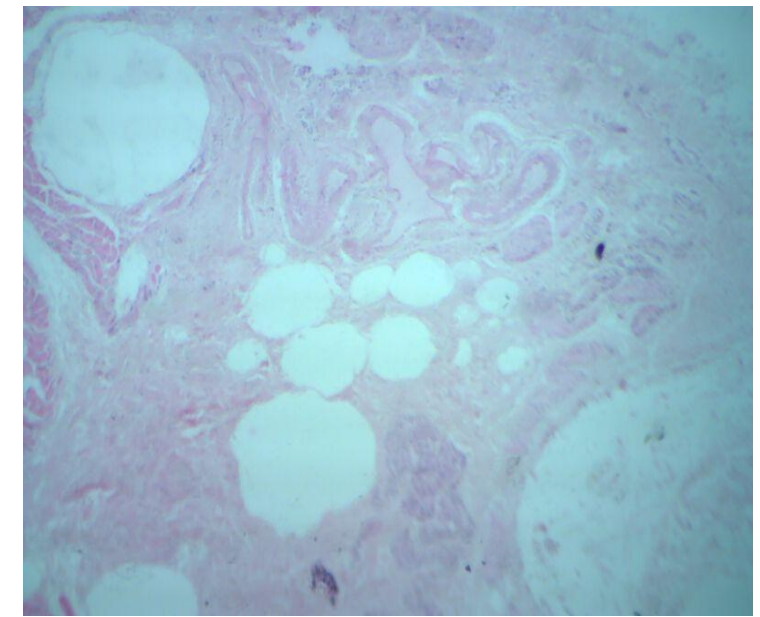

Figure (3):- Ovary of female rabbit treated by $1 \mathrm{ml}$ of castor oil group(III), showed necrosis (H\&EX40) 


\section{DISCUSSION}

In this study, revealed that treatment with castor seedslead to reduction in the body weight of the female rabbit with symptoms of diarrhea, dehydration, and death all groups were noticed at higher doses groups (IV). This may be is due to toxicity of the castor oil at higher doses, the seeds, leaves, and stems of the plant contain the glycoprotein ricin, which is poisonous to humans and animals. The most notorious uses of ricin have been as an assassination weapon by the secret intelligence services (Sani et al., 2007 and Sandhyakumary, 2003) stated that the ricin is one of the most potent naturally occurring toxins known to man, being next to plutonium and the phytotoxin abrin. It was also reported that ricin is twice as poisonous as cobra venom. If the castor seed is swallowed without chewing and there is no damage to the seed husk, it passes harmlessly through the digestive tract. However, if it is chewed and then swallowed, the intestines absorb the ricin toxin (Ogunkeye, 2000).

The results of the present study suggested that Ricinus communis RCE have a deleterious effect on female reproductive in $0.5 \mathrm{ml}$ completely destruct all layer and follicles and beginning of necrosis of the cell in $1 \mathrm{ml}$ present all layer ending of necrosis and present of tumor in cell may be the active material Ricinine which effect on the metabolic ways and the mean essential representation of decreasing the energy levels. However the poisoning material of Ricinine interfering with enzymes reaction in bodies tissue, such as reproductive system, then decreased the fertility or reproductive performance for these rabbit which represent the indicator for anticonceptive (Sandhyakumary, 2003) these result were accepted with Raji et al. (2006), they suggested that RCE possesses reversible antifertility and antiandrogenic properties. The mechanism involved in these activities may reside in the hypothalamicpituitary-gonadal axis (Prakash, 1979). The results of the present study suggested Ricinus communisseed extract has the potential to be developed into a female contraceptive agent

\section{RECOMMENDATION}

1 - This study can be continue with measurement level of estrogen-progesterone and we didn't that because of expensive of kit and shortness of the time.

2 - Can be study on all organs in the body of lab animal and can study on pregnant female animal to know the effect on the embryo.

3 - We recommend humans (female) to be seriously in use castor oil due to its affection on reproductive system.
4 - Can castor oil use as contraceptive in very few dose.

\section{REFERENCES}

Charles Obiero; Rhoda Birech; Joyce Maling'a; Kibet Ngetich and Bernhard Freyer (2014): Performance of Maize and Beans under Castor-based Intercropping System. American Journal of Experimental Agriculture; 4 (1): 101-113.

Nasir M. Cheema (2011): Yield and Chemical Composition of Castor Bean (Ricinus communis L.) as Influenced by Environment (PhD Thesis). Arid Agriculture University, Rawalpindi, Pakistan.

Banderjee, S.; Mukherjee, A.; Bandyopadhyay, SK.; Mukherjee, PK. and Sikdar, S. (1990): Preliminary studies on the anti-inflammatory effects of Ricinus communis India J. Pharmac; 22: 239-44.

Farid, J.; Al-Tahan, O. and Mustafa, A. (2011): Jasim Study of the effect of decorticated and defatted Castor Seeds (Ricinus Communis Linn.) on sperm functions and characters of male mice. Diyala Journal for Pure Science. 7: 3.

Jehan, Q.; Setty, BS. and Kar, AB. (1973): Studies on physiology and biochemistry of mammalian epididymis: effect of castration and steroid hormone replacement on sperm survival in rat epididymis. Indian J Exp Biol; 11: 270-3.

Al-Tahan, F.J. and Al-Shaha, O.M.S. (1990): A Primary Study on Castor Beans Cultivated in Iraq and its Content of the Toxic Substance Ricin. The Proceeding of the 2nd Technical Education Conference, Baghdad, Iraq. 227240. (in Arabic).

Sani et al., Nig. (2007): Journ. Pharm. Sci., October, 6 (2), 78-83.

Sandhyakumary, K.; Bobby, R.G. and Indira, M. (2003): Antifertility effects of Ricinus communis Linn. On rats. Phytother. Res. 17, 508-511.

Ogunkeye, C.O.; Okwuasaba, FK.; Uguru, VE. and Onoruvwe, O. (2000): Preliminary clinical investigation of the contraceptive efficacy and chemical pathological effects of RICOM-1013$\mathrm{J}$ of Ricinus communis var minor on women volunteers. Phytother Res; 14: 40-2.

Sandhyakumary, K.; Bobby, R.G. and Indira, M. (2003): Antifertility effects of Ricinus communis Linn. On rats. Phytother. Res. 17, 508-511.

Raji, Y.; Oloyo, AK. and Morakinyo, AO. (2006): Effect of methanol extract of Ricinus communis seed on reproduction of female rats. Asian J Androl.; 8(1): 115-21.

Prakash, A.O. (1979): Effects of Embelia ribs Brum. extracts on the uterus of rat. A histological study. probe, 18 (3): 178-184. 


$$
\text { براسة تاثير بذور الخروع على وظائف ومميزات المبيض لأنثى الاراتب عبد الحمبي عبد الله ، انتظار رفعت سرحت ، سهام عجمي وادي }
$$

Email: Buthinaabad67@yahoo.com Assiut University web-site: www.aun.edu.eg

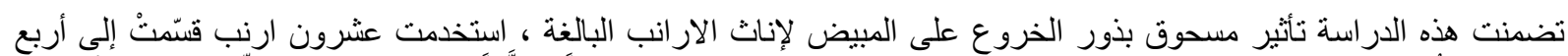

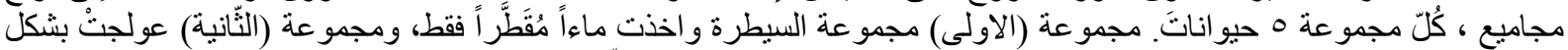

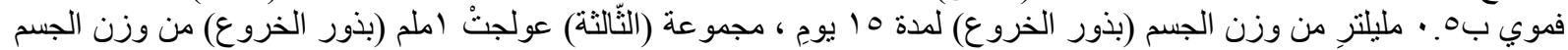

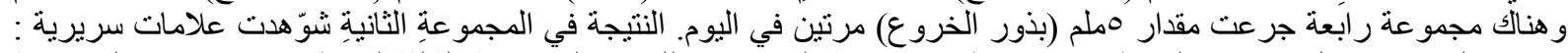

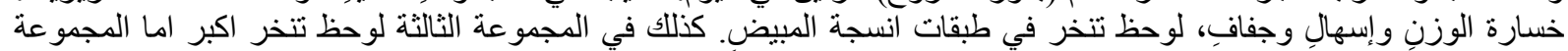

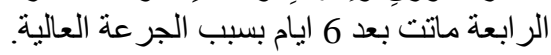

